\title{
Bilateral Bifid Condylar Process
}

\author{
Proceso Condilar Bífido Bilateral
}

"Kaan Gunduz; "**Hakan Avsever \& ${ }^{* * *}$ Umit Karacayli

GUNDUZ, K.; AVSEVER, H. \& KARACAYLI, U. Bilateral bifid condylar process. Int. J. Morphol., 28(3):941-944, 2010.

SUMMARY: The bifid condylar process is a rare alteration that is usually diagnosed as an incidental finding in a panoramic radiograph. The etiology of bifid condylar process is unknown, although the most tenable theory is that of traumatic origin. A 46-year-old woman was referred to our dental department with a complaint of pain and clicking on her temporomandibular joints. A panoramic radiograph showed bilateral bifid condyles Described with bifid condylar process varies from case to case, however in most cases are asymptomatic. The most common and predominant symptoms are temporomandibular joints sounds. The diagnosis of bifid condylar process is based on its radiographic appearance. Some researchers have indicated the necessity of imaging the anomaly by a second imaging method obtained in a different plane, in addition to orthopantomograph, and they have employed different techniques such as $\mathrm{CT}$ and magnetic resonance imaging. The bifid condylar process, and particularly the bilateral bifid condylar process, is a rare finding, the etiology of which remains uncertain. It is predominately an asymptomatic condition, discovered by chance on routine radiographic survey. The diagnosis is based on the radiographic manifestations and the treatment is usually conservative.

KEY WORDS: Bifid condylar process; Computed tomography; Panoramic.

\section{INTRODUCTION}

The bifid condylar process $(\mathrm{BCP})$ is a rare developmental anomaly first described in 1941 (Hrdlicka, 1941), and only a few cases have been reported since. It is characterized by the duplicity of the head of the mandibular condyle; thus it is also known as double-headed condyle and it may be associated with a variety of symptomps (Antoniades et al., 2004). Several factors have been cited as possible causes of BCP, but exact etiology is still unknown (Loh \& Yeo, 1990; Szentpétery et al., 1990). BMC is generally diagnosed as an incidental finding on routine radiographic examination (Szentpétery et al.). It usually affects only one condylar process, bilateral presentation is uncommon (Antoniades et al.). This paper reports a clinical rare case of bilateral $\mathrm{BCC}$ with specific radiologic features.

\section{CASE REPORT}

A 46-year-old woman was referred to the Department of Oral Diagnosis and Radiology with a complaint of pain and clicking in her temporomandibular joints (TMJ). She had no history of systemic disease and did not use any medication. Her physical examination showed no skeletal relationships alteration. Mouth opening was normal. Patient denied having had any previous trauma, fracture, or infection, nor any symptoms related tooth of the mandibular condyle. A panoramic radiograph showed bilateral bifid condylar process (Fig.1). The open-closed lateral radiograph of the TMJ, which was obtained by using the TMJ-specific program of the panoramic device, evaluated the existence of bilateral bifid condyle in the duplication of the right and left condyles (Fig. 2). Computer tomography (CT) of both joints was taken to rule out or eliminate any pathology such as fractures that might be missed with conventional radiographs. The CT indicated bifid formation of both condylar process with no degenerative sings (Fig. 3).

Treatment was conservative with an occlusal splint, soft diet, anti-inflammatories and muscle relaxants. The symptoms regressed and she is being followed up in our Oral Diagnosis and Radiology Department.

\footnotetext{
* Assistant Professor, Department of Oral Diagnosis and Radiology, Ondokuz May1s University, Faculty of Dentistry, Samsun, Turkey

** Assistant Professor, Department of Oral Diagnosis and Radiology, Gulhane Military Medical Academy, Ankara, Turkey

*** Associate Professor, Department of Oral and Maxillofacial Surgery, Gulhane Military Medical Academy, Ankara, Turkey.
} 


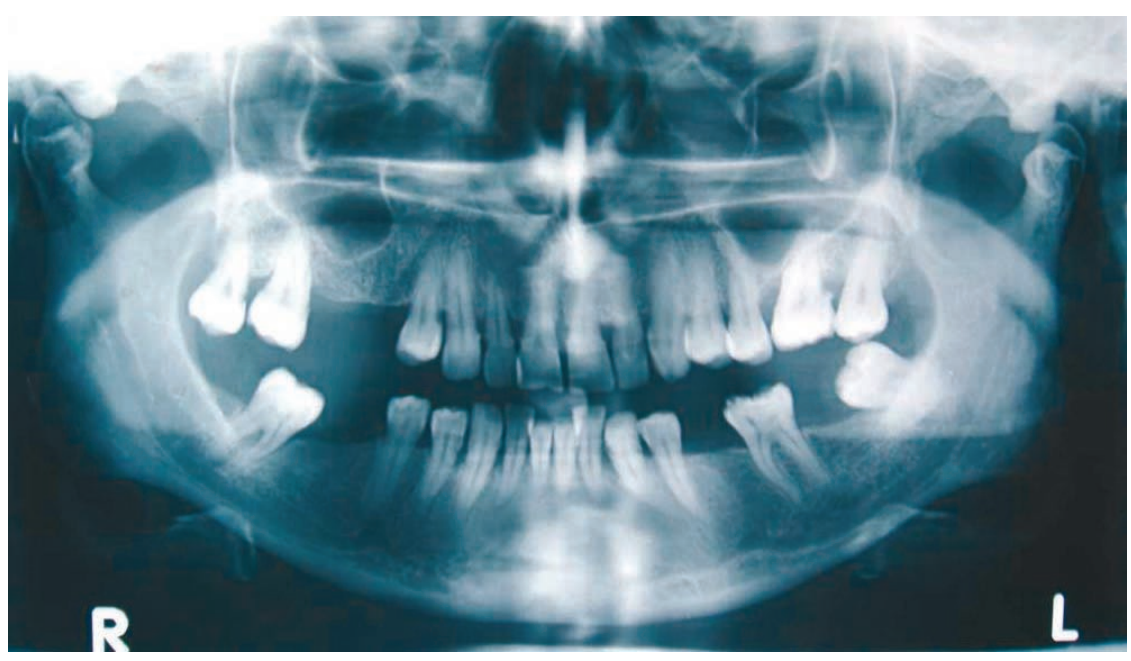

Fig. 1. Panoramic radiograph displaying duplication of both condyles.
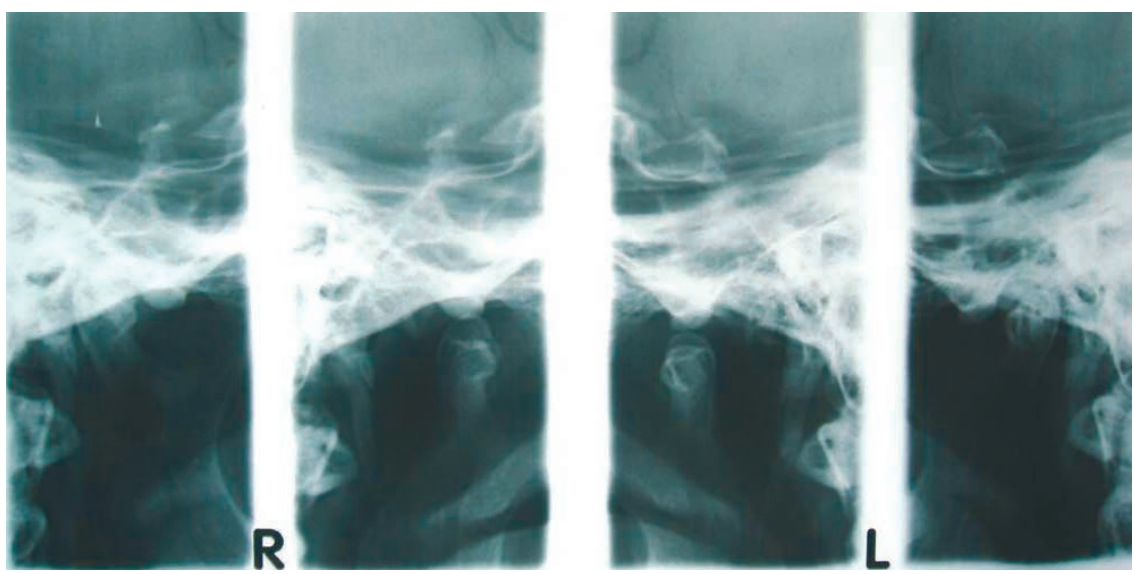

Fig. 2. Open-closed lateral radiograph of temporomandibular joint showing the the joint head orientation in the mediolateral direction on the right and left side.

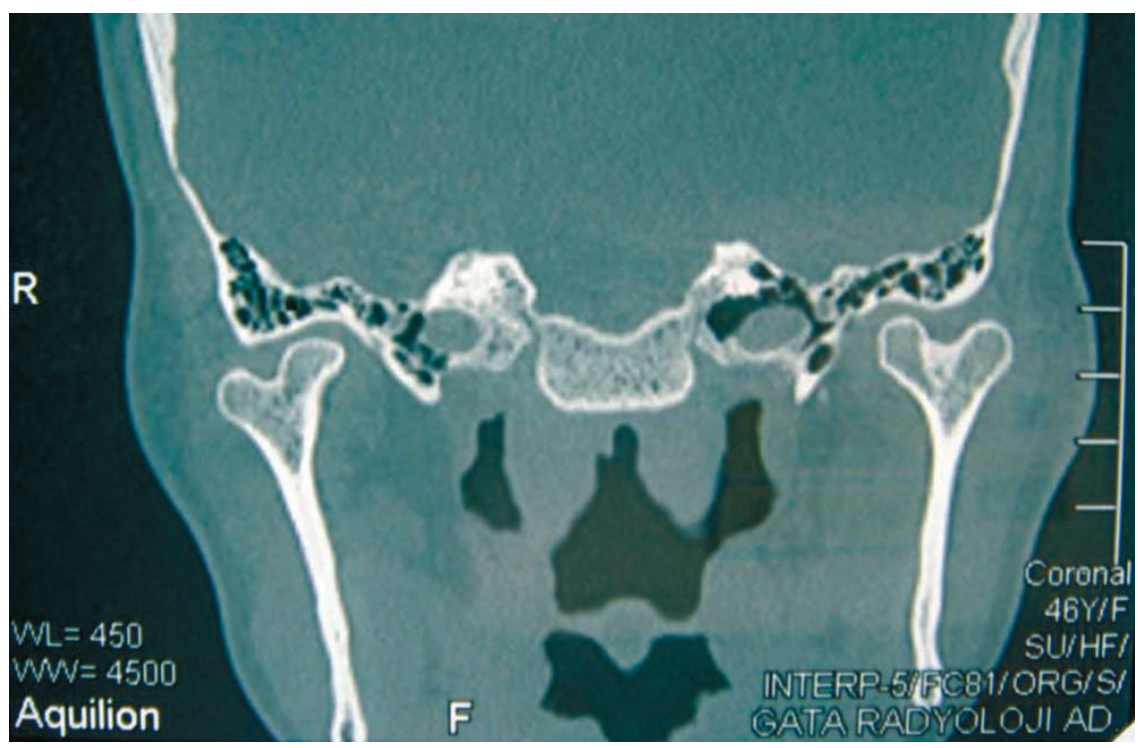

Fig. 3. Coronal computed tomography with coronal and central plane scars. The high resolution sections indicate bilateral bifid mandibular condyles. Note the widening of the temporomandibular joints as a result of the bifid configuration of the mandibular condyles.

\section{DISCUSSION}

The etiology of $\mathrm{BCC}$ is unknown; two major differing theories have been postulated to account for the pathogenesis of the mandibular condyle duplication. Blackwood (1957) and Moffett (1966) stated that the condylar cartilage, during the early stages of its development, is divided by wellvascularized fibrous septa and suggested that persistence of such a septum, in exaggerated form, within the growing cartilage might lead to an error in development that would in turn give rise to the bifid condition. This author also mentioned rupture of septal blood vessels as another possible cause of BCP. This theory might explain how forceps delivery, if it caused hematoma, could lead to BCP formation. However, Gundlach et al. (1987) found no evidence of persistent septa in the cases of BCP that they examined. The other theory, Thomason \& Yusuf (1986) have suggested prior trauma as a cause; however, the duplication has been described in patients without any history of identifiable traumatic event. In the case presented, the patient denied having had any previous trauma or fracture.

Symptoms described with $\mathrm{BCP}$ varies from case to case, however in most cases are asymptomatic. The most common and predominant symptoms are TMJ sounds (Antoniades et al.). Apart from the asymptomatic cases, pain, swelling, articular clicking, limited ability to open the mouth, deviation to the affected side, and ankylosis have also been reported (Quayle \& Adams, 1986). In our case, pain and clicking were the patient's chief complaints.

The diagnosis of $\mathrm{BCP}$ is based on its radiographic appearance, which 
is usually found coincidentally. Some researchers have indicated the necessity of imaging the anomaly by a second imaging method obtained in a different plane, in addition to orthopantomograph, and have employed different techniques such as $\mathrm{CT}$ and magnetic resonance imaging (MRI) (Açikgöz, 2006).

The condylar splitting ranges from a shallow groove to 2 distinct condyles with a separate neck (Stefanou et al., 1998). In our case both condyles showed 2 distinct condylar head with mediolateral orientation, similar to observations of Fuentes et al. (2009)

Treatment in $\mathrm{BCP}$ cases is usually conservative and similar to the treatment for the closely associated TMJ pain dysfunction syndrome (analgesics, anti-inflammatory agents, muscle relaxants, physiotherapy, splint) (Quayle et al.). Surgical treatment is described in TMJ anklyosis that used to appeared in BCP secondary to trauma (Corchero-Martín et al., 2005).

GUNDUZ, K.; AVSEVER, H. \& KARACAYLI, U. Proceso condilar bífido bilateral. Int. J. Morphol., 28(3):941-944, 2010.

RESUMEN: El proceso condilar bífido es una alteración rara que usualmente se diagnostica como un hallazgo incidental en una radiografía panorámica. La etiología de proceso condilar bífido es desconocida, aunque la teoría más aceptable es la de origen traumático. Una mujer de 46 años de edad, fue remitida a nuestro servicio dental con presencia de dolor y clic en sus articulaciones temporomandibulares. Una radiografía panorámica mostró procesos condilares bífidos bilaterales. La descripción del proceso condilar mandibular bífido varía de caso a caso, sin embargo en la mayoría de los casos son asintomáticos. Los síntomas más comunes y predominantes son los sonidos en las articulaciones temporomandibulares. El diagnóstico de proceso condilar bífido se basa en su aspecto radiográfico. Algunos investigadores han indicado la necesidad de proyección de imagen de la anomalía por un segundo método de imagen obtenida en un plano diferente, además de ortopantomografía, y han empleado diferentes técnicas como la tomografía computarizada y resonancia magnética. El proceso condilar bífido, y en particular bilateral, es un hallazgo poco frecuente, cuya etiología sigue siendo incierta. Es predominantemente una enfermedad asintomática, descubierta por casualidad en examen radiográfico de rutina. El diagnóstico se basa en las manifestaciones radiográficas y el tratamiento suele ser conservador.

PALABRAS CLAVE: Proceso condilar bífido; Tomografía computarizada; Panorámica.

\section{REFERENCES}

Açikgöz, A. Bilateral bifid mandibular condyle: a case report. J. Oral Rehabil., 33:784-7, 2006.

Antoniades, K.; Hadjipetrou, L.; Antoniades, V. \& Paraskevopoulos, K. Bilateral bifid mandibular condyle. Oral Surg. Oral Med. Oral Pathol. Oral Radiol. Endod., 97:535-8, 2004.

Blackwood, H. J. J. The double-headed mandibular condyle. Am. J. Phys. Anthropol., 15:1-8, 1957.

Corchero-Martín, G.; Gonzalez-Terán, T.; García-Reija, M. F.; Sánchez-Santolino, S. \& Saiz-Bustillo, R. Bifid condyle: case report. Med. Oral Patol. Oral Cir. Bucal., 10:277-9, 2005.

Fuentes, F. R.; Flores, F. O.; Silva, M. H.; Flores, L. T. Bifid condylar process: cases report. Int. J. Morphol., 27(2):539-41, 2009.

Gundlach, K. K.; Fuhrmann, A. \& Beckmann-Van der Ven, G. The double-headed mandibular condyle. Oral Surg. Oral Med. Oral Pathol., 64:249-3, 1987.
Hrdlicka, A. Lower jaw: double condyles. Am. J. Phys. Anthropol., 28:75-89, 1941.

Loh, F. C. \& Yeo, J. F. Bifid mandibular condyle. Oral Surg. Oral Med. Oral Pathol., 69:24-7, 1990.

Moffett, B. The morphogenesis of the temporomandibular joint. Am. J. Orthod., 52:401-15, 1966.

Quayle, A. A. \& Adams, J. E. Supplemental mandibular condyle. Br. J. Oral Maxillofac. Surg., 24:349-56, 1986.

Stefanou, E. P.; Fanourakis, I. G.; Vlastos, K. \& Katerelou, J. Bilateral bifid mandibular condyles. Report of four cases. Dentomaxillofac. Radiol., 27:186-8, 1998.

Szentpétery, A.; Kocsis, G. \& Marcsik, A. The problem of the bifid mandibular condyle. J. Oral Maxillofac. Surg., 48:1254-7, 1990.

Thomason, J. M. \& Yusuf, H. Traumatically induced bifid mandibular condyle: report of two cases. Br. Dent. J., 161:291-3, 1986. 
GUNDUZ, K.; AVSEVER, H. \& KARACAYLI, U. Bilateral bifid condylar process. Int. J. Morphol., 28(3):941-944, 2010.

Correspondence to:

Umit Karacayli, DDS, PhD

Gulhane Military Medical Academy

Department of Oral and Maxillofacial Surgery

Ankara

TURKEY

Tel: +903123046043

Fax: +90 3123046020

Email: ukaracayli@gmail.com ukaracayli@gata.edu.tr

Received: 16-03-2010

Accepted: 24-07-2010 